\title{
The Occurrence of Brassicasterol in the Diatoms, Cyclotella nana and Nitzschia closterium
}

\author{
Akio Kanazawa, Mitsuki Yoshioka, and Shin-ichi Teshima* \\ (Received March 25, 1971)
}

\begin{abstract}
Very little information has been reported about the sterol in diatoms. In this paper, the sterol composition of the marine diatoms, Cyclotella nana and Nitzschia closterium was investigated.

The sterols from Cyclotella and Nitzschia gave the melting point of $148^{\circ} \mathrm{C}$ and the molecular weight of 398 (mass spectrum). In gas-liquid chromatography on four different columns, this algal sterols were found to be composed of only one component identified as brassicasterol. Infrared absorption spectra and mass spectra analyses also supported the structure of brassicasterol.
\end{abstract}

On the occurrence of sterols in the algae, many reports have been presented up to the present ${ }^{1,2)}$. However, very little information has been reported about the diatoms. HeILBRON $^{3)}$ suggested that Nitzschia closterium contains fucosterol. It has also been reported by Low ${ }^{4}$ that the principal sterol of Navicula pelliculosa is a $\Delta^{7}$-stenol, provisionally identified as chondrillasterol.

The authors have been studied on the sterol metabolism in marine invertebrates ${ }^{5-10}$. In the course of these investigations, it has been demonstrated that some sterols occurring in marine crustaceans may originate from diets. The diatoms are generally good diet for the larvae of marine animals. Hence, the authors intended to clarify the sterol composition of diatoms. In the present investigation, the sterol composition of the marine diatoms, Cyclotella nana and Nitzschia closterium has been examined.

\section{Materials and Methods}

Diatoms. Cyclotella nana and Nitzschia closterium were kindly supplied by Dr. $\mathbf{H}$. TAKANO and Mr. O. UMEBAYASH of Tokai Regional Fisheries Research Laboratory.

The diatoms were grown on the TA-medium ${ }^{11)}$ with the following solutes: $\mathrm{NaCl}$, $11.75 \mathrm{~g} ; \mathrm{MgCl}_{2} \cdot 6 \mathrm{H}_{2} \mathrm{O}, 5.30 \mathrm{~g} ; \mathrm{Na}_{2} \mathrm{SO}_{4} \cdot 10 \mathrm{H}_{2} \mathrm{O}, 4.45 \mathrm{~g} ; \mathrm{CaCl}_{2} \cdot 2 \mathrm{H}_{2} \mathrm{O}, 0.073 \mathrm{~g} ; \mathrm{KCl}, 0.33 \mathrm{~g}$; $\mathrm{NaNO}_{3}, 300 \mathrm{mg} ; \mathrm{K}_{2} \mathrm{HPO}_{4}, 10 \mathrm{mg} ; \mathrm{NaHCO}_{3}, 200 \mathrm{mg} ; \mathrm{Na}_{2} \mathrm{SiO}_{3}, 100 \mathrm{mg}$; EDTA, $10 \mathrm{mg}$; Vitamin $\mathrm{B}_{12}, 0.015 \mu \mathrm{g} ; \mathrm{FeSO}_{4} \cdot 7 \mathrm{H}_{2} \mathrm{O}, 3 \mathrm{mg}$; Citric acid, $3 \mathrm{mg} ; \mathrm{H}_{3} \mathrm{BO}_{3}, 1.5 \mathrm{mg} ; \mathrm{MnCl}_{2}$. $4 \mathrm{H}_{2} \mathrm{O}, 1 \mathrm{mg} ; \mathrm{ZnSO}_{4} \cdot 7 \mathrm{H}_{2} \mathrm{O}, 22 \mu \mathrm{g} ; \mathrm{CuSO}_{4} \cdot 5 \mathrm{H}_{2} \mathrm{O}, 79 \mu \mathrm{g} ;\left(\mathrm{NH}_{4}\right)_{6} \mathrm{Mo}_{7} \mathrm{O}_{24} \cdot 4 \mathrm{H}_{2} \mathrm{O}, 15 \mu \mathrm{g}$; $\mathrm{NH}_{4} \mathrm{VO}_{3}, 23 \mu \mathrm{g} ; \mathrm{CoCl}_{2} \cdot 6 \mathrm{H}_{2} \mathrm{O}, 15 \mu \mathrm{g}$ per liter; $\mathrm{pH}$ 7.6. The culture was incubated in 1 liter Erlenmeyer flasks containing $700 \mathrm{ml}$ of the incubation medium at $23^{\circ} \mathrm{C}$ under the

* Faculty of Fisheries, Kagoshima University. Shimoarata-cho, Kagoshima City (金讯昭夫·吉岡 満城・手島新一：䧹児島大学水产学部) 